\title{
Influence of Extrusion Processing on Fatty acids Retention in Full-fat Flaxseed (Linum usitatissimum L.) Meal
}

\author{
Muhammad Imran ${ }^{1 *}$, Faqir Muhammad Anjum² and Muhammad Umair Arshad ${ }^{1}$ \\ ${ }^{1}$ Department of Food Science, Government College University, Faisalabad-38040, Pakistan \\ ${ }^{2}$ National Institute of Food Science and Technology, University of Agriculture, Faisalabad-38040, Pakistan
}

\begin{abstract}
Background: Flaxseed (Linum usitatissimum L.) provides multiple nutritional benefits including high quality protein, dietary fiber and is the most abundant source of $\alpha$-linolenic acid $\left(\mathrm{C}_{18: 3}\right)$. This study focuses on the effect of extrusion processing on fatty acids retention in full-fat flaxseed meal. The ranges of processing variables selected using central composite design were: barrel exit temperature (BET) of $76.3-143.6^{\circ} \mathrm{C}$; screw speed (SS) of 59.6-160.5 $\mathrm{rpm}$ and feed rate $(\mathrm{FR})$ of $26.4-93.6 \mathrm{~kg} / \mathrm{h}$.

Results: The extrusion processing at different barrel temperatures, screw speed and feed rate did not showed gradual decrease or increase in palmitic, stearic, oleic and linoleic acid contents. The amount of a-linolenic acid retention in extruded samples ranged from $92 \%$ to $99.2 \%$. Optimal operating conditions were established; BET $\left(138.4-138.8^{\circ} \mathrm{C}\right)$, SS $(160-160.5 \mathrm{rpm})$ and FR $(26.4-34.1 \mathrm{~kg} / \mathrm{h})$ for maximum $(98.3-98.8 \%)$ retention of $\alpha$-linolenic acid. This effect was mainly dependent on BET $(p \leq 0.01)$, whereas mutual interaction effect of BET, SS and FR was found to be non-significant $(p>0.05)$.
\end{abstract}

Conclusions: The results of this study demonstrated that the extrusion processing can be successfully explored to produce fatty meals with significant fatty acids retention for commercially food or feed purposes.

Keywords: Extrusion; Fatty acids; Flaxseed; $\alpha$-Linolenic acid; Retention; RSM

\section{Introduction}

The flaxseed (Linum usitatissimum L.) is one of the world's oldest domesticated crops, which is cultivated as either an oil or fiber crop. The "flaxseed" and "linseed" are terms often used interchangeably. The shape of flaxseed is flat or oval upto 4-6 $\mathrm{mm}$ size with a pointed tip and color varies from dark-brown to pale-yellow [1]. The world flaxseed production remained static about 2.5 million tones as compared with other oilseed crops and represents $1 \%$ of total world oilseeds supply [2]. The flaxseed in human nutrition provides high dietary fiber and abundance of $\alpha$-linolenic acid $\left(\mathrm{C}_{18: 3}\right)$ contents. The human consumption of flaxseed includes adding it ready-to-eat (RTE), breakfast cereals, breakfast drinks, specialty breads, muffins, and other bakery products in Europe and Asia [3]. The intake of flaxseed omega-3 fatty acids decreases serum cholesterol, which beneficially affects blood pressure, thrombosis, atherosclerosis, arterial compliance and hyperlipidaemia response $[4,5]$.

Extrusion is defined as "shaping by force through a specially designed opening often after previous heating of the material" [6]. The extrusion in general is a high temperature and short time (HTST) thermal processing technology which is extensively employed in food and feed industries. Ready-to-use extruded fatty meals are not largely available on the commercial scale due to technological drawback of oil percolation at die during processing whole seeds having lipid content $>16 \%$ [7]. The fatty acids contents such as $\alpha$-linolenic, linoleic and oleic fatty acids show more vulnerable attraction towards degradation under high temperature thermal processing $[8,9]$.

Extrusion cooking modeling for quality changes involves numerous process input parameters and multiple product output properties. The response surface methodology is a mathematical and statistical approach which has been widely used for optimizing the response of multivariate parameters during modeling of extrusion processing $[10,11]$. The objective of this study was to investigate the influence of extrusion processing of full-fat flaxseed at different barrel exit temperatures, screw speeds, and feed rates on the retention of fatty acids using response surface methodology.

\section{Materials and Methods}

The flaxseed (cv. Chandni) was procured from Oilseeds Research Institute, Faisalabad, Pakistan. Seeds were cleaned to remove any debris or field dirt and stored in sealed polyethylene bags at $5 \pm 1{ }^{\circ} \mathrm{C}$.

\section{Extrusion processing}

Single-screw extruder, Extru-tech E325 (Extru-tech, Sabetha, Kansas, USA), with a barrel length (BL) to diameter (LD) ratio of 9:1 was used for the production of full-fat flaxseed meal. This extruder is divided into six zones along the length of the barrel, with Zone-1 designated as inlet section and Zone- 6 nearest the barrel discharge/exit section. The screws and steamlocks configuration were arranged in such a manner to provide a progressively tighter pitch and greater resistance from inlet section to outlet zone. Inlet section was characterized with a wide flight tapered screws, zone 2, 3 and 4 desirably with intermediate flight spacing while zone 5 and 6 were affixed with tight flight screws to compress the raw material. Temperature probe was set at the end of

*Corresponding author: Muhammad Imran, Department of Food Science Government College University, Faisalabad-38040, Pakistan, Tel: +92-3157054723; E-mail: imran@gcuf.edu.pk

Received July 22, 2013; Accepted September 25, 2013; Published October 05 2013

Citation: Imran M, Anjum FM, Arshad MU (2013) Influence of Extrusion Processing on Fatty acids Retention in Full-fat Flaxseed (Linum usitatissimum L.) Meal. J Food Process Technol 4: 268. doi:10.4172/2157-7110.1000268

Copyright: (c) 2013 Imran M, et al. This is an open-access article distributed unde the terms of the Creative Commons Attribution License, which permits unrestricted use, distribution, and reproduction in any medium, provided the original author and source are credited. 
barrel section for the determination of barrel exit temperature (BET). Medium shear extruder classification was used for all experiments. The feed rate (FR) for different treatments was calculated with in relation to feeder speed (FS). The FS was set at different rates $(8,12,16$, or $20 \mathrm{rpm}$ ) for variable processing times $(1,2$, or $3 \mathrm{~min})$. The average material collected during different FS was used for the development of regression equation and FR was determined accordingly. The extruded samples were cooled down to room temperature and placed in sealed polyethylene bags at $5 \pm 1^{\circ} \mathrm{C}$ for fatty acids analysis.

\section{Fatty acids profile}

The fatty acids profile of flaxseed oil was carried out according to the method described in AOCS [12] Method No. Ce 1f-96. Briefly, the oil sample $(50 \mu \mathrm{l})$ was methyated in the presence of $4 \mathrm{~mL} \mathrm{KOH} \mathrm{(1} \mathrm{M)} \mathrm{at}$ room temperature for $1 \mathrm{~h}$ in order to produce fatty acids methyl esters. The resultant methyl esters were extracted with GC grade n-hexane and immediately analyzed through Gas Chromatograph (Varian 3900) apparatus equipped with an auto sampler, flame-ionization detector (FID) and supelco wax column (30 $\mathrm{m} \times 0.25 \mu \mathrm{m}$ film coating). The samples $(1 \mu \mathrm{L})$ were injected with Helium $(1 \mathrm{~mL} / \mathrm{min})$ as a carrier gas onto the column, which was programmed for operating conditions such as column oven temperature $160^{\circ} \mathrm{C} @ 0$ minutes with subsequent increase of $3^{\circ} \mathrm{C} / \mathrm{min}$ until $180^{\circ} \mathrm{C}$. The column oven temperature was increased from $180^{\circ} \mathrm{C}$ to $220^{\circ} \mathrm{C} @ 1^{\circ} \mathrm{C} / \mathrm{min}$ and was held for $7.5 \mathrm{~min}$ at $220^{\circ} \mathrm{C}$. Split ratio was $50 \%$ with injector $240^{\circ} \mathrm{C}$ and detector $250^{\circ} \mathrm{C}$ temperatures. The peak areas and total fatty acids composition were calculated for each sample by retention time using Varian Chem Station software.

\section{a-Linolenic acid retention}

The retention of $\alpha$-linolenic acid in flaxseed samples obtained as a result of different extrusion runs was calculated according to expression given below:

$$
\alpha-\text { Linolenic acid retention, } \%=\frac{\text { The content of } \alpha-\text { linolenic acid after extrusion }}{\text { The content of } \alpha-\text { linolenic acid in raw material }} \times 100
$$

\section{Experimental design and statistical analysis}

A three factors (barrel exit temperature, screw speed and feed rate) and five levels $(-1.682,-1,0,1,+1.682)$ multiple regression analysis was carried out to achieve the maximal information about dependent variables from a minimal number of possible experiments using central composite design (Table 1) and analysis of experiments was carried out according to Montgomery [13].

For better accuracy and simplification of result interpretation, the coded multiple regression coefficients were used and reconverted into original values at the end of experiment. Each experiment was performed in replicate and the average values were taken as response, Y. The experimental data was fitted to second order polynomial response model and regression coefficients of linear, quadratic and interaction terms were obtained. The analysis of variance (ANOVA) with 95\% confidence level was then employed for $\alpha$-linolenic acid response variable in order to test the model significance and suitability using MATLAB' (Ver. 7.9.0) software (Mathworks, Inc., Natick, USA). The significance of all terms in the polynomial model was analyzed statistically by computing mean square at probability (p) of 0.01 or 0.05 .

\section{Results and Discussion}

The palmitic, stearic, oleic, linoleic and $a$-linolenic acids found in tested raw flaxseed samples were 5.6\%, 4.2\%, 15.8\%, 14.7\% and 55.4\%, respectively. The fatty acids composition of flaxseed samples as a result of different extrusion runs has been depicted in Table 2. The results revealed that extrusion conditions did not significantly affect the composition of fatty acids content. The literature concerning effects of extrusion processing on fatty acids retention in oilseed meals is limited. The palmitic acid concentration ranged from a minimum value of $4.6 \%$ to a maximum value of $5.3 \%$ as a result of different extrusion runs. The lowest value $(3.6 \%)$ of stearic acid was found as a result of extrusion run 16 (barrel exit temperature, $110^{\circ} \mathrm{C}$; screw speed, $59.6 \mathrm{rpm}$ and feed rate, $60 \mathrm{~kg} / \mathrm{h}$ ). Wicklund and Magnus [14] reported non-significant differences in distribution of palmitic and stearic acids for raw and extruded oat flour.

The oleic acid contents were found to vary 15.8 to $16.4 \%$ in extruded flaxseed samples. The oleic acid contents were observed to increase at higher barrel temperature which may be due to transition of polyunsaturated fatty acids in the more saturated state characterized with smaller number of double bonds. Gómez et al. [15] reported decrease in polyunsaturated fatty acids after extrusion processing of instant whole corn flour. The extrusion processing at low barrel temperatures, high screw speed and high feed rate did not showed gradual decrease in linoleic contents. The extrusion processing of fullfat soya bean cultivars at a temperature of $150^{\circ} \mathrm{C}$ for 30 seconds did not significantly affect the linoleic acid content [16]. The fatty acids distribution of lipid fractions extracted from corn meal samples were found similar before and after extrusion [17]. The level of moisture present in raw feed material also provides protection against losses of unsaturated fatty acids during thermal heating [18].

\section{Effect of extrusion processing on $\alpha$-Linolenic acid retention}

The combinations of independent variables for extrusion optimization and $\alpha$-linolenic acid retention in extruded flaxseed meal have been shown in Table 2. The results indicated that $\alpha$-linolenic acid content in extruded flaxseed samples ranged from $92 \%$ to $99.2 \%$. The extrusion run point 8 (Barrel exit temperature, $90^{\circ} \mathrm{C}$; screw speed, 140 $\mathrm{rpm}$ and feed rate, $40 \mathrm{~kg} / \mathrm{h}$ ) exerted maximum retention $(99.2 \%)$ of $\alpha$-linolenic acid content. The lowest $\alpha$-linolenic acid retention $(92 \%)$ was for extrusion run 4 (Barrel exit temperature, $143.6^{\circ} \mathrm{C}$; screw speed, $110 \mathrm{rpm}$ and feed rate, $60 \mathrm{~kg} / \mathrm{h}$ ).

The predicted values of $a$-linolenic acid retention in extruded flaxseed samples were calculated using regression model and were found within the range of experimental values. Several indicators such as coefficient of determination $\left(\mathrm{R}^{2}\right)$, adjusted coefficient of determination $\left(\mathrm{R}^{2}{ }_{\text {adj }}\right)$, coefficients of the variation $(\mathrm{CV})$ and model

\begin{tabular}{|c|c|c|c|c|}
\hline \multirow{2}{*}{ Independent variable } & \multicolumn{3}{|c|}{ Coded levels } \\
\cline { 2 - 5 } & -1.682 & -1 & 0 & 1 \\
\hline Barrel exit temperature $\left({ }^{\circ} \mathrm{C}\right)$ & 76.3 & 90 & 110 & 130 \\
\hline Screw speed $(\mathrm{rpm})$ & 59.6 & 80 & 110 & 1.682 \\
\hline Feed rate $(\mathrm{kg} / \mathrm{h})$ & 26.4 & 40 & 60 & 140 \\
\hline
\end{tabular}

Table 1: Coded and actual levels of independent variables used for optimization of single-screw processing conditions as determined by the central composite design (CCD). 
Citation: Imran M, Anjum FM, Arshad MU (2013) Influence of Extrusion Processing on Fatty acids Retention in Full-fat Flaxseed (Linum usitatissimum L.) Meal. J Food Process Technol 4: 268. doi:10.4172/2157-7110.1000268

Page 3 of 5

\begin{tabular}{|c|c|c|c|c|c|c|c|c|}
\hline \multirow{2}{*}{ Extrusion run } & \multicolumn{3}{|c|}{ Independent variables } & \multicolumn{5}{|c|}{ Fatty acids (\% of total weight) } \\
\hline & $\mathrm{BET}\left({ }^{\circ} \mathrm{C}\right)$ & SS (rpm) & $\mathrm{FR}(\mathrm{kg} / \mathrm{h})$ & Palmitic acid & Stearic acid & Oleic acid & Linoleic acid & a-Linolenic acid retention \\
\hline 1 & -1.682 & 0 & 0 & 5.2 & 4.1 & 15.8 & 14.6 & 98.9 \\
\hline $2\left(C_{1}\right)$ & 0 & 0 & 0 & 5.0 & 4.0 & 16.0 & 14.5 & 95.7 \\
\hline $3\left(C_{2}\right)$ & 0 & 0 & 0 & 4.9 & 3.9 & 16.0 & 14.5 & 95.8 \\
\hline 4 & 1.682 & 0 & 0 & 4.7 & 3.8 & 16.4 & 14.2 & 92.0 \\
\hline 5 & -1 & -1 & -1 & 5.1 & 4.1 & 15.9 & 14.3 & 98.4 \\
\hline 6 & 0 & 1.682 & 0 & 5.3 & 4.1 & 15.9 & 14.6 & 98.3 \\
\hline $7\left(\mathrm{C}_{3}\right)$ & 0 & 0 & 0 & 5.0 & 4.0 & 16.0 & 14.5 & 95.9 \\
\hline 8 & -1 & 1 & -1 & 4.8 & 4.1 & 15.8 & 14.5 & 99.2 \\
\hline $9\left(\mathrm{C}_{4}\right)$ & 0 & 0 & 0 & 4.9 & 4.0 & 16.0 & 14.5 & 95.8 \\
\hline 10 & 1 & -1 & -1 & 4.6 & 3.8 & 16.2 & 14.3 & 94.7 \\
\hline 11 & 0 & 0 & 1.682 & 4.8 & 3.7 & 15.9 & 14.4 & 96.5 \\
\hline 12 & 1 & 1 & -1 & 4.7 & 4.0 & 16.1 & 14.5 & 96.3 \\
\hline 13 & 1 & 1 & 1 & 4.9 & 3.9 & 16.1 & 14.5 & 95.0 \\
\hline 14 & -1 & -1 & 1 & 5.1 & 3.9 & 15.8 & 14.4 & 97.5 \\
\hline 15 & 0 & 0 & -1.682 & 4.8 & 3.8 & 16.1 & 14.5 & 98.2 \\
\hline 16 & 0 & -1.682 & 0 & 4.7 & 3.7 & 16.2 & 14.3 & 97.4 \\
\hline $17\left(C_{5}\right)$ & 0 & 0 & 0 & 4.9 & 4.0 & 16.0 & 14.5 & 95.9 \\
\hline 18 & 1 & -1 & 1 & 4.7 & 3.8 & 16.1 & 14.3 & 93.6 \\
\hline 19 & -1 & 1 & 1 & 5.1 & 4.0 & 15.8 & 14.5 & 98.1 \\
\hline $20\left(\mathrm{C}_{6}\right)$ & 0 & 0 & 0 & 5.0 & 4.1 & 16.0 & 14.5 & 95.8 \\
\hline
\end{tabular}

$\mathrm{C}_{1}, \mathrm{C}_{2}, \mathrm{C}_{3}, \mathrm{C}_{4}, \mathrm{C}_{5}, \mathrm{C}_{6}=$ Center points in central composite design.

Table 2: Percent values of fatty acids content in extruded flaxseed samples as determined by the central composite design (CCD).

significance (F-value) can also be used to determine the adequacy of the second-order polynomial response model. The coefficient of determination $\left(R^{2}\right)$ is defined as the ratio of the explained variation to the total variation [19]. This value indicates the relevance of the dependent variables in the model and the small value of $R^{2}$ shows the poor relevance of the dependent variables. The $\mathrm{R}^{2}$ and $\mathrm{R}_{\text {adj }}^{2}$ for the second-order polynomial regression model equation were found 0.9829 and 0.9676 which explained about $98.29 \%$ and $96.76 \%$, respectively of the variability observed and good fitness of the model. Low value of CV (0.34) indicated a very high degree of precision and a good deal of reliability of the experimental values.

The effects of process variables were regressed and respective regression equations were developed. The second-order polynomial model equation obtained for $\alpha$-linolenic acid retention is given as under:

$$
\begin{aligned}
& Y=95.8279-1.8455 x_{1}+0.433 x_{2}-0.5315 x_{3}+0.2 x_{1} x_{2} \\
& -0.05 x_{1} x_{3}-0.05 x_{2} x_{3}-0.203 x_{1}^{2}+0.6454 x_{2}^{2}+0.4687 x_{3}^{2}
\end{aligned}
$$

The second-order polynomial regression equations developed as a function of independent variables in terms of coded factors for $\alpha$-linolenic acid retention are given as under:

$$
\begin{aligned}
& Y 1=99.809+0.0199 x_{1}-0.0005 x_{1}^{2} \\
& Y 2=102.9184-0.1433 x_{2}+0.0007 x_{2}^{2} \\
& Y 3=101.6506-0.1674 x_{3}+0.0011 x_{3}^{2} \\
& \text { Where } \\
& Y=i \text { s the response } \\
& Y 1=i \text { is the barrel exit temperature, }{ }^{\circ} \mathrm{C} \\
& Y 2=i \text { s the screw speed }, \mathrm{rpm} \\
& Y 3=i \text { s the feed rate, } \mathrm{kg} / \mathrm{h}
\end{aligned}
$$

The exploration and optimization of a fitted response model equation may produce poor or misleading results, unless the model presents the linear, quadratic and mutual interaction by good fit statistical analysis. The statistical testing of the model was done in the form of variance by fitting of the experimental data and results have been summarized in Table 3 . The mean square values were obtained by dividing the sum of squares of each of the two sources of variation (model and error variance) by the respective degree of freedom. The linear and quadratic model effects were observed more significant as compared to interaction effects $(\mathrm{p} \leq 0.01)$. The coefficient estimates indicated that the largest effect on $\alpha$-linolenic acid retention was the linear term of barrel temperature $(p<0.0001)$, followed by the linear term of screw speed and feed rate $(p<0.05)$. The quadratic terms of screw speed and feed rate were significant, and further cross product coefficients $\left(\beta_{B E T \times S S}, \beta_{B E T \times F R}, \beta_{S S \times F R}\right)$ were found to be non-significant $(\mathrm{p}>0.05)$.

The relationship between the response and the experimental independent variables can be explained on the basis of three-dimensional surface plots. Such graphical plots are supportive in studying the interaction effects of independent variables and consequently in determining the optimal response condition. The mutual impact of barrel temperature and screw speed on $\alpha$-linolenic acid retention by setting the feed rate at $60 \mathrm{~kg} / \mathrm{h}$ has been depicted in Figure 1A. The vertical axes in the diagram showed retention of $\alpha$-linolenic acid and horizontal axes represented barrel exit temperature and screw speed variables. The barrel temperature and screw speed did not mutually show an effect on $\alpha$-linolenic acid retention. The maximum predicted value of $\alpha$-linolenic acid retention (99.3-99.6\%) was found with a $79.3-81.9^{\circ} \mathrm{C}$ of barrel and $151.5-152.4 \mathrm{rpm}$ speed of screws. Increase in barrel temperature at low screw speed decreased $\alpha$-linolenic acid retention in extruded flaxseed samples. Twin-screw extrusion at a temperature of $180^{\circ} \mathrm{C}$ and screw speed $300 \mathrm{rpm}$ did not show change in free polyenoic fatty acids and $\alpha$-linolenic acid composition of oat flour extrudates [20]. However, Manthey et al. [21] reported apparent decline in $\alpha$-linolenic acid contents for flaxseed based spaghetti during extrusion processing. The content of linolenic acid dropped (by 6 to $12 \%$ ) in extruded full-fat soya bean samples processed at a temperature of $120^{\circ} \mathrm{C}$ as reported by Zilic et al. [16] The decrease in $\alpha$-linolenic acid retention may be attributed to holding time effect on feed material, low 


\begin{tabular}{|c|c|c|c|c|}
\hline \multicolumn{2}{|c|}{ Source of variation } & df & Mean square & $p$ value \\
\hline & Intercept & 9 & $7.0^{* *}$ & $<0.0001$ \\
\hline Linear & $B E T$ & 1 & $46.52^{* *}$ & $<0.0001$ \\
\hline & $S S$ & 1 & $2.56^{* *}$ & 0.0007 \\
\hline & $F R$ & 1 & $3.86^{* *}$ & 0.0001 \\
\hline Interaction & $B E T: S S$ & 1 & $0.32^{\text {NS }}$ & 0.1182 \\
\hline & $B E T: F R$ & 1 & $0.02^{\text {NS }}$ & 0.6782 \\
\hline & SS:FR & 1 & $0.01^{\text {NS }}$ & 0.677 \\
\hline Quadratic & BET:BET & 1 & $0.59^{*}$ & 0.0421 \\
\hline & SS:SS & 1 & $6.0^{* *}$ & $<0.0001$ \\
\hline & FR:FR & 1 & $3.17^{* *}$ & 0.0003 \\
\hline \multicolumn{2}{|c|}{ Residual } & 10 & 0.11 & - \\
\hline \multicolumn{2}{|c|}{ Lack of Fit } & 5 & $0.21^{* *}$ & 0.0006 \\
\hline \multicolumn{2}{|c|}{ Pure Error } & 5 & 0.005 & - \\
\hline
\end{tabular}

** Significant at 0.01 level * Significant at 0.05 level NS Non-significant

Table 3: ANOVA of the predicted second-order polynomial model for $\alpha$-linolenic acid retention in extruded flaxseed samples.

rotation of screws and increased barrel temperature [15]. The transition of $\alpha$-linolenic acid content to more saturated state and conversion of double bonds configuration from cis to trans after disruption of seed cell walls at higher barrel temperature also led towards destruction of essential fatty acids activity $[8,22]$.

The basic purpose of response surface methodology application is to find a set of independent variable conditions that ensure the maximum response of the desired output variable. The maximum predicted value $99.3-99.5 \%$ of $\alpha$-linolenic acid retention was found with a $79.2-81.9^{\circ} \mathrm{C}$ of barrel temperature and $31.7-32.3 \mathrm{~kg} / \mathrm{h}$ feed rate by fixing the screw speed at $110 \mathrm{rpm}$ (Figure 1B). A remarkable retention of $\alpha$-linolenic acid content was noted at low feed rate and low barrel temperature which is supported by the study of Wicklund and Magnus [14] who found a non-significant effect of extrusion temperature $\left(150^{\circ} \mathrm{C}\right)$ on recovery of $\alpha$-linolenic acid in sifted oat flour. The alteration in fatty acids composition during thermal treatment of raw materials may be due to lipolytic activity, interactions between lipids and other constituents or processing conditions. The extrusion of raw and pre-conditioned linseed at $120^{\circ} \mathrm{C}$ showed non-significant reduction in $\alpha$-linolenic acid contents [23] .

Maximum $\alpha$-linolenic acid retention (98.9-99.4\%) was obtained by setting the barrel temperature at $110{ }^{\circ} \mathrm{C}$ and at a screw speed 159.7-160.1 rpm and feed rate 40.2-50.1 kg/h (Figure 1C). The mutual influence of screw speed and feed rate was found to be nonsignificant. It is also obvious from the results that decrease in rotation of screws with increased feed rate negatively influenced $a$-linolenic acid retention. The extrusion of flaxseed at low rotation of screw with high feed rate may increase residence time in extruder barrel which negatively influenced retention of $\alpha$-linolenic acid. The reduced feed rate led towards significant retention of $\alpha$-linolenic acid content which is supported by the study of Kong et al. [24] who found non-significant differences in $\alpha$-linolenic acid contents among salmon fillet treatments before and after lab-scale twin screw extrusion cooking. The sorghummaize-soy blends prepared at extruded high barrel temperature did not show significant changes in oleic, linoleic and linolenic fatty acids content when compared with raw feed material [25].

\section{Conclusion}

The results of this study demonstrated that the full-fat flaxseed extrusion was an effective processing in the retention of fatty acids.
The extrusion processing at different barrel temperatures, screw speed and feed rate did not showed gradual decrease or increase in palmitic, stearic, oleic and linoleic acid contents. The amount of $\alpha$-linolenic acid
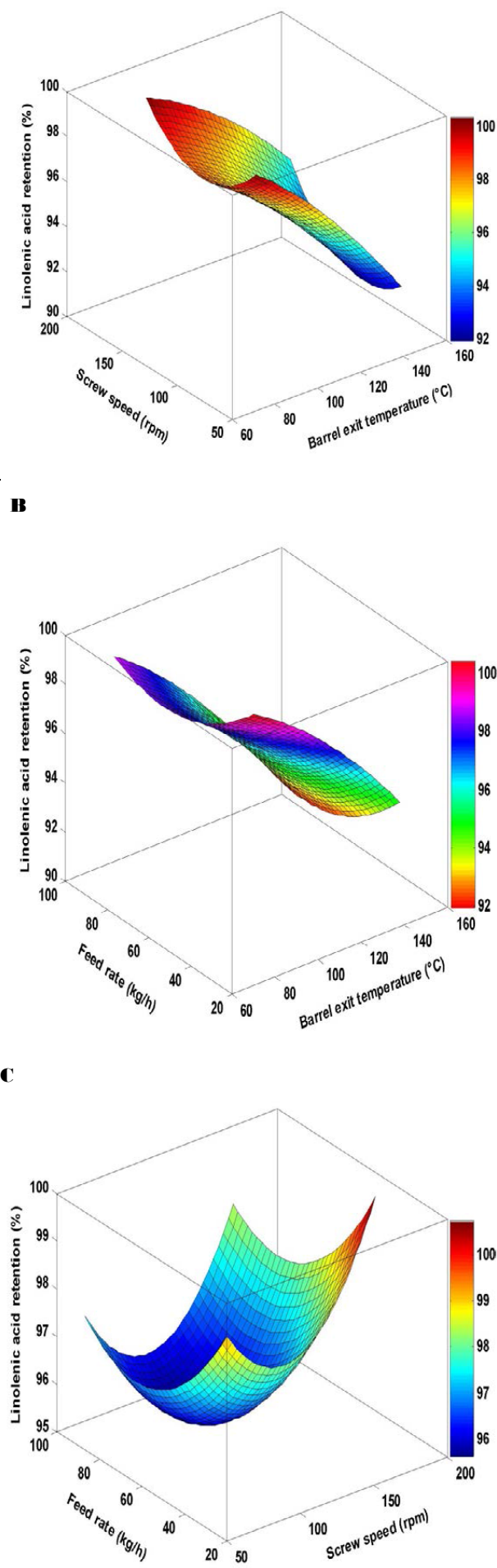

Figure 1: Mutual interaction effect of barrel exit temperature $\left(B E T,{ }^{\circ} \mathrm{C}\right)$, screw speed $(\mathrm{SS}, \mathrm{rpm})$ and feed rate $(\mathrm{FR}, \mathrm{kg} / \mathrm{h})$ on the $\alpha$-linolenic acid retention during flaxseed meal production at: (A) feed rate-FR $60 \mathrm{~kg} / \mathrm{h}$; $(B)$ at screw speed-SS, $110 \mathrm{rpm}$; and (C) at barrel exit temperature-BET, $110^{\circ} \mathrm{C}$ 
Citation: Imran M, Anjum FM, Arshad MU (2013) Influence of Extrusion Processing on Fatty acids Retention in Full-fat Flaxseed (Linum usitatissimum L.) Meal. J Food Process Technol 4: 268. doi:10.4172/2157-7110.1000268

retention in extruded flaxseed meal samples ranged from $92 \%$ to $99.2 \%$. Based on the results of this study, it can be concluded that extrusion cooking can be successfully used for oilseed meals production with significant fatty acids retention for commercially food or feed purposes.

\section{Acknowledgment}

This work was supported by Higher Education Commission (HEC), Islamabad, Pakistan. Authors thank HEC of Pakistan for support of this research.

\section{Conflict of Interest}

The authors have no conflict of interest

\section{References}

1. Pradhan RC, Meda V, Naik SN, Tabil L (2010) Physical Properties of Canadian Grown Flaxseed in Relation to its Processing. Int J Food Prop 13: 732-743.

2. FAOSTAT (2009) World Linseed Production and Import/Export Data, FAO Database: Food and Agriculture Organization of the United Nations.

3. Dybing CD, Lay C (1981) Flax Linum usitatissium, In: Handbook of Biosolar Resource, ed. by MacClure TA, Lipinsky ES. CRC Press, New York, pp. 71-85.

4. Gebauer SK, Psota TL, Harris WS, Kris-Etherton PM (2006) n-3 fatty acid dietary recommendations and food sources to achieve essentiality and cardiovascular benefits. Am J Clin Nutr 83: 1526S-1535S.

5. Yashodhara BM, Umakanth S, Pappachan JM, Bhat SK, Kamath R, et al. (2009) Omega-3 fatty acids: a comprehensive review of their role in health and disease. Postgrad Med J 85: 84-90.

6. Harper JM (1978) Food extrusion. CRC Crit Rev Food Sci Nutr 11: 155-215

7. Pilli TD, Severini C, Baiano A, Derossi A, Arhaliass A, et al. (2005) Effects of operating conditions on oil loss and properties of products obtained by corotating twin-screw extrusion of fatty meal: preliminary study. J Food Eng 70 : 109-116.

8. Camire ME, Camire A, Krumhar K (1990) Chemical and nutritional changes in foods during extrusion. Crit Rev Food Sci Nutr 29: 35-57.

9. Ilo S, Schoenlechner R, Berghofe E (2000) Role of lipids in the extrusion cooking processes. Grasas y Aceites 51: 97-110

10. Ganjyal GM, Hanna MA, Jones DD (2003) Modeling Selected Properties of Extruded Waxy Maize Cross-Linked Starches with Neural Networks. J Food Sci 68: 1384-1388.

11. Shihani N, Kumbhar BK, Kulshreshtha M (2006) Modeling of extrusion process using response surface methodology and artificial neural networks. J Eng Sci Tech 1: $31-40$
12. AOCS (1998) Official Methods and recommended Practices of AOCS, American Oil Chemists Society. Champaign, IL, USA

13. Montgomery DC (2008) Response Surface Methods and Designs. In: Design and analysis of experiments. Wiley, New York, USA, p. 440

14. Wicklund T, Magnus EM (1997) Effect of Extrusion Cooking on Extractable Lipids and Fatty Acid Composition in Sifted Oat Flour. Cereal Chem 74: 326329

15. Aldapa CAG, Bustos FM, Cárdenas JDF, Falomir CAO, Hernández JG (1996) Chemical and nutritional changes during preparation of whole corn tortillas prepared with instant flour obtained by extrusion process. Arch Latinoam Nutr 46: 315-319.

16. Žilić SM, Šobajić SS, Snežana D, Drinić M, Kresović BJ, et al. (2010) Effects of heat processing on soya bean fatty acids content and the lipoxygenase activity. J Agric Sci 55: 55-64.

17. Guzman LB, Lee TC, Chichester CO (1992) Lipid Binding During Extrusion Cooking. In: Food Extrusion Science and Technology, ed. by Kokini JL, Ho C-T, Karwe MV. Marcel Dekker, New York, USA, pp. 427-436.

18. Yoshida H, Kajimoto G (1988) Effect of Microwave Treatment on the Trypsin Inhibitor and Molecular Species of Triglycerides in Soybeans. J Food Sci 53 1756-1760.

19. Wang Y, Li D, Wang LJ, Chiu YL, Chen XD, et al. (2008) Optimization of extrusion of flaxseeds for in vitro protein digestibility analysis using response surface methodology. J Food Eng 85: 59-64.

20. Zadernowski R, Nowak-Polanska H, Wicklund T, Fornal L (1997) Changes in oat lipids affected by extrusion. Nahrung 41: 224-227.

21. Manthey FA, Lee RE, Hall CA 3rd (2002) Processing and cooking effects on lipid content and stability of alpha-linolenic acid in spaghetti containing ground flaxseed. J Agric Food Chem 50: 1668-1671

22. Grela ER, Jensen SK, Jakobsen K (1999) Fatty acid composition and conten of tocopherols and carotenoids in raw and extruded grass pea (Lathyrus sativus L.). J Sci Food Agr 79: 2075-2078.

23. Akraim F, Nicot MC, Weill P, Enjalbert $F$ (2006) Effects of preconditioning and extrusion of linseed on the ruminal biohydrogenation of fatty acids. 1. In vivo studies. Anim Res 55: 83-91.

24. Kong J, Dougherty MP, Perkins LB, Camire ME (2008) Composition and consumer acceptability of a novel extrusion-cooked salmon snack. J Food Sci 73: S118-123

25. Nicole M, Fei HY, Claver IP (2010) Characterization of Ready-to-Eat Composite Porridge Flours Made by Soy-Maize-Sorghum-Wheat Extrusion Cooking Process. Pakistan J Nutr 9: 171-178. 